\title{
Ascorbic acid and pectin in different sizes and parts of citric fruits
}

\author{
Ácido ascórbico e pectina em diferentes partes de frutas cítricas de vários tamanhos
}

\author{
Larissa Akemi YWASSAKI ${ }^{1}$, Solange Guidolin CANNIATTI-BRAZACA ${ }^{2 *}$
}

\begin{abstract}
Citric fruits - in natura, as frozen pulp or even as juice - are one of the most important Brazilian exportation products. They are a source of ascorbic acid - a potent antioxidant, and pectin, which is used in the food industry and is an important dietary fiber. This project aims to quantify ascorbic acid and pectin contents in citric fruits, commercial oranges and tangerines, comparing them in sizes and varieties. Ascorbic acid amount was measured in juice comparing sizes, varieties and storage conditions, using a tritimetric method with 2.6-dichlorobenzenoindophenol indicator. Total and soluble pectin in each part of the fruits (peel, albedo, pulp and juice) were quantified using the polygalacturonic acid as a standard. Differences were found between the sizes. The highest content of vitamin $\mathrm{C}$ was found in the oranges (Bahia variety). Comparing the storage temperatures, the biggest loss was at room temperature. Albedo presented the highest content of pectin in all fruits. In juice, the total and soluble pectin contents increased as fruits size decreased. Oranges and tangerines differed in the amount of pectin.
\end{abstract}

Keywords: orange; tangerine; pectin; ascorbic acid; composition; size.

\section{Resumo}

Os produtos de frutas cítricas são de grande importância para as exportações do Brasil in natura, polpa congelada e ainda na forma de suco. São fonte de ácido ascórbico, potente antioxidante, e pectina, que é utilizada na indústria e também é importante fibra alimentar. A pesquisa teve como objetivo quantificar o ácido ascórbico em frutas cítricas, laranjas e tangerinas comerciais, comparando tamanhos e variedades. O teor de ácido ascórbico foi medido no suco comparando os tamanhos, variedades e condições de estocagem, usando método de titulação com 2,6-diclorobenzenoindofenol. A pectina total e solúvel foi quantificada em partes da fruta (casca, albedo, polpa e suco), sendo usado como padrão o ácido poligalacturônico. Foram encontradas diferenças entre tamanhos. As maiores quantidades de vitamina $\mathrm{C}$ foram encontradas nas laranjas (variedade Bahia). Comparando as temperaturas de estocagem, a maior perda ocorreu à temperatura ambiente. O albedo apresentou a maior quantidade de pectina em todos os frutos. No suco, o total de pectina solúvel e insolúvel aumentou com a diminuição do tamanho dos frutos. Laranjas e tangerinas diferiram quanto ao teor de pectinas.

Palavras-chave: laranja; tangerina; pectina; ácido ascórbico; composição; tamanho.

\section{Introduction}

Citric fruits are originally from Asia, especially from China and the Malaysian archipelago, and are of different shapes and colors. The fruiting occurs all year long, but mainly between April and September (GRUPO COLT, 2003).

There are several new citrus hybrids in the world (RAPISARDA et al., 2009). In Brazil, mutation of wild species has resulted in the production of an orange variety internationally known as Bahia orange or Washington Navel (HASSE, 1987; ASSOCIAÇÃO..., 2003).

Vitamin C, carotenoids, pectin and phenolic compounds are important components of citrus. The phenolic antioxidants of fruit juices protect the vitamin $\mathrm{C}$ content from oxidative degradation. The identifiable soluble phenolic compounds of orange are hesperidin and nanrirutin, but the major antioxidant is the ascorbic acid. Orange juice also contains carotenoids, mainly cryptoxanthis, lutein, anthoxanthin, violaxantin, which do not mix with the water soluble antioxidant components.
Hesperidin and narirutin flavones are abundant in orange juice in a partially dissolved, partially suspended and partially colloidal form (DAUCHET et al., 2008; GHASEMI; GHASEMI; EBRAHINZADEH, 2009; XU et al., 2008).

Among fruits and vegetables, citrus fruits are the ones with the highest pectin content in all their parts: peel, albedo, juice and pip (RAI et al., 2006).

Responsible for the firmness and texture of fruits and vegetables, pectin became important in food industries as gel forming and thickening agents (BRUMMELL, 2006; MAFRA et al., 2006). In food industries, pectic substances are widely used in the manufacture of jams, jellies, marmalades, and fruit preserves of all kinds, especially the natural pectin content of fruits, like orange peel (ZYKWINSKA et al., 2009).

There is a relationship between the consumption of fibers and the decrease of blood cholesterol (KANG et al., 2009). 
Pectin can alter the digestion and absorption of lipids (METZGER; BARNES; REED, 2009; OVODOV, 2009). The high methoxyl pectin is more effective than the low one for reducing blood cholesterol, $30-40 \mathrm{~g}$ reduce $10 \%$ of cholesterol level in blood (CIPRIANI et al., 2009; FIETZ; SALGADO, 1999; FRANCO, 2001). Piedade and Canniatti-Brazaca (2003) found out that fibers from leaves are not as effective, after comparing high methoxyl pectin and fibers from pineapple leaves in lowering of blood cholesterol.

This project aims to quantify the vitamin $\mathrm{C}$ contents in citric fruits, comparing sizes, varieties and storage conditions, and to compare the influence of varieties on the pectin levels of different citrus - in different parts and of different sizes.

\section{Materials and methods}

\subsection{Material}

Two dozen of each one of the following citrus varieties, in different sizes (small, medium and large), were used in this study. We also quoted their origin and collection date: Sample 1 - 'Pêra' orange; Sample 2 - 'Valência' orange; Sample 3 - 'Lima' orange; Sample 4 - 'Natal' orange; Sample 5 - 'Bahia' (Washington Navel) orange; Sample 6 - 'Ponkan' tangerine; Sample 7 - 'Murcote' tangor.

\subsection{Methodology}

\section{Sample Standardization}

All the samples were standardized by analyzing their proximal composition (water, ash, lipids, protein and carbohydrates) (ASSOCIATION..., 1995).

For these analyses, we used 6 fruits of each size (small, medium and large), except the peels. They were dried in stove $\left(55^{\circ} \mathrm{C}\right)$ and grinded before the analyses.

\section{Determination of dietary fiber method}

In these analyses, we used the albedo, pulp and seeds by Asp et al. (1983) method. It uses the $\alpha$-amylase heat-stable enzyme (A-3306 Sigma ${ }^{\text {tw }}$ St. Louis USA) to hydrolyze starch and pepsin $\left(\right.$ VETEC $^{\mathrm{m}} \mathrm{R}$ Rio de Janeiro RJ, Brazil) followed by pancreatin (From Porcine pancreas P-1625 Sigma ${ }^{\text {mu }}$ St. Louis USA) for protein degradation.

For these analyses we used 6 fruits of each size (small, medium and large). They were dried in stove $\left(55^{\circ} \mathrm{C}\right)$ and grinded before the analyses.

\section{Samples standardization}

The maturation of samples was measured using total solid soluble ( ${ }^{\circ}$ Brix) and titratable acidity according to Pregnolatto (1985). The ratio between them was calculated.

The juice of three fruits was used after extraction and homogenization for each treatment.

\section{Determination of Ascorbic acid}

Ascorbic acid amount was measured in samples immediately after extraction of juice and after 24 hours. The storage was done at room temperature and at $4{ }^{\circ} \mathrm{C}$ in dark screw cap flask. Ascorbic acid was measured using a tritimetric method, 2.6-dichlorobenzenoindophenol indicator (JACOBS, 1958; LEME JUNIOR; MALAVOLTA, 1950).

The juice of three fruits was used after extraction and homogenization for each treatment.

\section{Determination of pectin}

Pectin (total and soluble) was quantified in juice, pulp, albedo and peel, through McCready and McComb (1952) method. Bitter and Muir (1962) technique was used for dosage, and the results were expressed in $\mathrm{mg}$ of polygalacturonic acid per $100 \mathrm{~g}$ of fresh fruit.

For all samples, we used 12 fruits of each size (small, medium and large), peeled and with all the parts separated manually, trying to keep the minimum of albedo in the peel and the most of it together with the pulp. The samples were dried in oven $\left(55^{\circ} \mathrm{C}\right)$ and then grinded. The juice was extracted manually and froze immediately.

\section{Statistics}

The delineation was made totally at random. The F Test was realized for average comparison and, if it were significant, the Tukey Test was performed - the SAS software (STATISTICAL..., 1996) was used. The significance level used was $5 \%$.

\section{Results and discusion}

All the samples were of ripe fruits, but their different sizes were a result of factors such as water amounts (from soil, air, irrigation and rain), low temperatures, deficient or inappropriate plant nutrition, biological factors (plague, senile trees and excessive flowering) or tree location (BECERRA-RODRIGUEZ et al., 2008; LESTER; JIFON; ROGER, 2005; PESTANA et al., 2005).

The data showed by FCF (UNIVERSIDADE..., 2008), USDA (UNITED..., 2009), RLC/FAO (OFICINA...; FOOD..., 2004) and TACO/UNICAMP (UNIVERSIDADE..., 2006) are similar to the data found (Table 1) for some items of the fruits composition, but, in general, the results of this study were higher for items like proteins, ash and total fibers; the water amounts were lower and the lipids amounts were the nearest. 'Natal' orange stood out for its ash amounts. Lipids amounts in tangerine and tangor were higher than in three varieties of oranges, and the lipids amounts were similar in 'Valência' and 'Pêra.' The highest lipids amounts were found in 'Pêra' orange. For insoluble fibers, the highest amounts were found in 'Bahia' and 'Natal' oranges and in 'Ponkan' tangerine, although the lowest soluble fibers amounts were found in 'Natal' and 'Valência' oranges, too.

Changes in water amounts can occur because of long periods of rain and low temperatures, which can delay the fruits ripeness and influence their characteristics (Tables 1 and 2).

Table 2 shows smaller differences for water amounts between the sizes of tangerine and tangor, occurring only in oranges. The highest water amounts were found in the large size fruits and the lowest ones in the small size fruits, with significant differences in some varieties $(\mathrm{p} \leq 0.05)$. The ash amounts were higher in the small size fruits, except in the 'Valência' orange. There were no statistical differences between 
sizes for 'Bahia' orange $(\mathrm{p} \leq 0.05)$. A similar behavior is observed for lipids, the highest levels were detected in the smaller fruits and there were no significant statistical differences between the sizes, the same occurring in protein amounts. In this case, 'Lima' orange presented a reduction in the protein level despite the size increase; protein levels in 'Ponkan' tangerines were very close; and for 'Natal' orange, the medium sized fruits presented the highest values followed by the small sized ones and then, by the large sized. Culture treatments, pluviosity and weather conditions may influence these values (BECERRARODRIGUEZ et al., 2008; LESTER; JIFON; ROGER, 2005; PESTANA et al., 2005).

Analyzing the total fibers contents, the highest values were found in the small sized 'Pêra' and 'Lima' oranges.

Except for 'Bahia' orange, the soluble fibers content is lower than the insoluble one, as shown in Table 3. In most varieties, there was little values variation between the sizes. For oranges, the highest values for soluble fibers content were found in the small sized fruits; except for a few cases, there were no statistical differences $(\mathrm{p} \leq 0.05)$ among the medium sized fruits. Tangerine soluble fibers content presented statistical differences $(\mathrm{p} \leq 0.05)$ between the sizes.

Table 3 shows the highest values for insoluble fibers content in the small sized oranges, and in the medium sized 'Ponkan' tangerine.

The varieties did not present significant differences in the total soluble solids contents (Table 4 ). The titratable acidity presented a significant difference $(\mathrm{p} \leq 0.05)$ between the lime orange - with the lowest acid content, and 'Bahia' orange, which presented the highest titratable acidity.

Total solid soluble and titratable acidity in different sizes by variety are observed in Table 5.The medium and large sizes compared to the little size in lime oranges presented numerical differences. The large and medium sizes were harvested in rain season and lower temperature, retarding fruit maturation and altering the total soluble solids (Tables 4 and 5).

Sanchez-Moreno's et al. (2003) research on 'Valencia' variety found 11.3 soluble solids $\left({ }^{\circ} \mathrm{Brix}\right.$ at $\left.20^{\circ} \mathrm{C}\right), 1.12 \%$ titratable acidity and 10.09 TSS/TTA levels. For 'Pera' variety, it was found a TSS of 10.43 , a TTA of $2.2 \%$ and a TSS/TTA of 4.75 , according to

Table 1. Proximal composition ${ }^{1,2}$ of Citrus fruits $\left(\mathrm{g} .100 \mathrm{~g}^{-1}\right)$.

\begin{tabular}{|c|c|c|c|c|c|c|c|}
\hline Varieties & Water & Ash & Lipids & Protein & Insoluble Fiber & Soluble Fiber & $\mathrm{HCO}^{3}$ \\
\hline Pêra & $84.56 \pm 3.1^{\mathrm{a}}$ & $0.65 \pm 0.0^{\mathrm{b}}$ & $0.32 \pm 0.1^{\mathrm{abc}}$ & $1.61 \pm 0.1^{\mathrm{a}}$ & $6.54 \pm 1.1^{\mathrm{a}}$ & $2.45 \pm 0.3^{\mathrm{abc}}$ & 3.86 \\
\hline Valência & $89.21 \pm 0.6^{\mathrm{a}}$ & $0.73 \pm 0.2^{\mathrm{b}}$ & $0.31 \pm 0.0^{\mathrm{abc}}$ & $0.87 \pm 0.0^{\text {cde }}$ & $3.78 \pm 0.8^{\mathrm{ab}}$ & $0.39 \pm 0.2^{c}$ & 4.70 \\
\hline Lima & $86.27 \pm 3.3^{\mathrm{a}}$ & $0.52 \pm 0.0^{\mathrm{b}}$ & $0.18 \pm 0.1^{\mathrm{c}}$ & $1.03 \pm 0.2^{\mathrm{bcd}}$ & $4.37 \pm 2.2^{\mathrm{ab}}$ & $1.32 \pm 1.6^{\mathrm{abc}}$ & 6.30 \\
\hline Natal & $88.74 \pm 0.4^{\mathrm{a}}$ & $1.49 \pm 0.4^{\mathrm{a}}$ & $0.25 \pm 0.0^{\mathrm{bc}}$ & $0.68 \pm 0.1^{\mathrm{e}}$ & $1.77 \pm 0.1^{\mathrm{b}}$ & $0.84 \pm 0.1^{\mathrm{bc}}$ & 6.24 \\
\hline Bahia & $83.87 \pm 0.7^{a}$ & $0.67 \pm 0.0^{\mathrm{b}}$ & $0.15 \pm 0.1^{\mathrm{c}}$ & $1.28 \pm 0.1^{\mathrm{b}}$ & $3.12 \pm 0.5^{\mathrm{b}}$ & $3.08 \pm 0.2^{\mathrm{a}}$ & 7.24 \\
\hline Ponkan & $88.36 \pm 1.0^{\mathrm{a}}$ & $0.54 \pm 0.0^{\mathrm{b}}$ & $0.45 \pm 0.1^{\mathrm{ab}}$ & $0.83 \pm 0.0^{\mathrm{de}}$ & $2.96 \pm 0.3^{\mathrm{b}}$ & $1.04 \pm 1.1^{\mathrm{abc}}$ & 5.82 \\
\hline Murcote & $84.28 \pm 1.8^{\mathrm{a}}$ & $0.51 \pm 0.1^{\mathrm{b}}$ & $0.45 \pm 0.1^{\mathrm{a}}$ & $1.15 \pm 0.0^{\mathrm{bc}}$ & $4.28 \pm 0.3^{\mathrm{ab}}$ & $2.53 \pm 0.4^{\mathrm{ab}}$ & 6.80 \\
\hline
\end{tabular}

${ }^{1}$ Average of the three sizes (small, medium and large) \pm standard deviation. ${ }^{2}$ Different lowercase letters in a column indicate statistic differences ( $\left.\mathrm{p} \leq 0.05\right)$ between the varieties, for each item (water, ash, lipids, protein, insoluble fiber, soluble fiber and carbohydrates). ${ }^{3}$ Carbohydrates (HCO).

Table 2. Citrus fruits proximal composition ${ }^{1,2}$ by different sizes without peel (g.100 $\left.\mathrm{g}^{-1}\right)$.

\begin{tabular}{|c|c|c|c|c|c|c|c|}
\hline \multicolumn{2}{|c|}{ Varieties } & \multirow{2}{*}{$\frac{\text { Water }}{87.26 \pm 0.0^{\mathrm{a}}}$} & \multirow{2}{*}{$\begin{array}{c}\text { Ash } \\
0.64 \pm 0.0^{\mathrm{b}}\end{array}$} & \multirow{2}{*}{$\begin{array}{c}\text { Lipids } \\
0.23 \pm 0.0^{\mathrm{b}}\end{array}$} & \multirow{2}{*}{$\begin{array}{l}\text { Protein } \\
1.61 \pm 0.1^{\mathrm{a}}\end{array}$} & \multirow{2}{*}{$\begin{array}{c}\text { Dietetic fiber } \\
8.08\end{array}$} & \multirow{2}{*}{$\begin{array}{r}\mathrm{HCO}^{3} \\
2.18\end{array}$} \\
\hline Pêra & Large & & & & & & \\
\hline & Medium & $85.23 \pm 0.3^{b}$ & $0.61 \pm 0.0^{c}$ & $0.26 \pm 0.0^{\mathrm{b}}$ & $1.51 \pm 0.0^{\mathrm{a}}$ & 8.33 & 4.06 \\
\hline & Small & $81.18 \pm 0.4^{\mathrm{c}}$ & $0.70 \pm 0.0^{\mathrm{a}}$ & $0.48 \pm 0.1^{\mathrm{a}}$ & $1.72 \pm 0.2^{\mathrm{a}}$ & 10.57 & 5.35 \\
\hline \multirow[t]{4}{*}{ Valência } & Large & $89.84 \pm 0.1^{\mathrm{a}}$ & $0.95 \pm 0.1^{\mathrm{a}}$ & $0.30 \pm 0.0^{\mathrm{a}}$ & $0.92 \pm 0.0^{\mathrm{a}}$ & 4.69 & 3.40 \\
\hline & Medium & $88.78 \pm 0.1^{b}$ & $0.67 \pm 0.0^{\mathrm{b}}$ & $0.33 \pm 0.0^{\mathrm{a}}$ & $0.85 \pm 0.0^{\mathrm{a}}$ & 3.53 & 5.84 \\
\hline & Small & $89.02 \pm 0.2^{b}$ & $0.56 \pm 0.0^{\mathrm{b}}$ & $0.31 \pm 0.1^{\mathrm{a}}$ & $0.85 \pm 0.0^{\mathrm{a}}$ & 4.40 & 4.86 \\
\hline & Large & $88.88 \pm 0.1^{\mathrm{a}}$ & $0.47 \pm 0.0^{\mathrm{b}}$ & $0.14 \pm 0.0^{c}$ & $0.84 \pm 0.0^{c}$ & 3.60 & 6.07 \\
\hline \multirow[t]{2}{*}{ Lima } & Medium & $87.41 \pm 0.1^{\mathrm{b}}$ & $0.54 \pm 0.0^{\mathrm{a}}$ & $0.17 \pm 0.0^{\mathrm{b}}$ & $1.02 \pm 0.0^{\mathrm{b}}$ & 3.54 & 5.57 \\
\hline & Small & $82.51 \pm 0.1^{\mathrm{c}}$ & $0.55 \pm 0.0^{\mathrm{a}}$ & $0.24 \pm 0.0^{\mathrm{a}}$ & $1.24 \pm 0.1^{\mathrm{a}}$ & 9.94 & 5.52 \\
\hline \multirow[t]{3}{*}{ Natal } & Large & $89.22 \pm 0.2^{\mathrm{a}}$ & $1.62 \pm 0.2^{\mathrm{ab}}$ & $0.21 \pm 0.0^{\mathrm{b}}$ & $0.57 \pm 0.0^{c}$ & 2.46 & 5.92 \\
\hline & Medium & $88.58 \pm 0.1^{b}$ & $1.07 \pm 0.3^{\mathrm{b}}$ & $0.25 \pm 0.0^{\mathrm{ab}}$ & $0.76 \pm 0.0^{\mathrm{a}}$ & 2.51 & 6.83 \\
\hline & Small & $88.42 \pm 0.2^{b}$ & $1.77 \pm 0.2^{\mathrm{a}}$ & $0.29 \pm 0.0^{\mathrm{a}}$ & $0.70 \pm 0.0^{\mathrm{b}}$ & 2.86 & 5.96 \\
\hline \multirow[t]{3}{*}{ Bahia } & Large & $84.65 \pm 0.2^{\mathrm{a}}$ & $0.71 \pm 0.0^{\mathrm{a}}$ & $0.06 \pm 0.0^{\mathrm{b}}$ & $1.32 \pm 0.1^{\mathrm{a}}$ & 5.68 & 7.58 \\
\hline & Medium & $83.66 \pm 0.1^{b}$ & $0.63 \pm 0.1^{\mathrm{a}}$ & $0.23 \pm 0.1^{\mathrm{a}}$ & $1.22 \pm 0.0^{\mathrm{a}}$ & 6.16 & 8.10 \\
\hline & Small & $83.29 \pm 0.0^{\mathrm{b}}$ & $0.66 \pm 0.1^{\mathrm{a}}$ & $0.16 \pm 0.0^{\mathrm{ab}}$ & $1.31 \pm 0.1^{\mathrm{a}}$ & 6.76 & 6.03 \\
\hline \multirow[t]{3}{*}{ Ponkan } & Large & $87.26 \pm 0.1^{b}$ & $0.56 \pm 0.0^{\mathrm{a}}$ & $0.49 \pm 0.0^{\mathrm{a}}$ & $0.86 \pm 0.0^{\mathrm{a}}$ & 5.04 & 5.79 \\
\hline & Medium & $88.95 \pm 0.2^{\mathrm{a}}$ & $0.52 \pm 0.0^{\mathrm{b}}$ & $0.38 \pm 0.0^{\mathrm{b}}$ & $0.80 \pm 0.0^{\mathrm{b}}$ & 3.33 & 6.03 \\
\hline & Small & $88.87 \pm 0.1^{\mathrm{a}}$ & $0.55 \pm 0.0^{\mathrm{ab}}$ & $0.48 \pm 0.0^{\mathrm{a}}$ & $0.82 \pm 0.0^{\mathrm{ab}}$ & 3.65 & 5.63 \\
\hline \multirow[t]{3}{*}{ Murcote } & Large & $85.49 \pm 0.0^{\mathrm{a}}$ & $0.35 \pm 0.1^{\mathrm{b}}$ & $0.40 \pm 0.0^{\mathrm{b}}$ & $1.09 \pm 0.1^{\mathrm{a}}$ & 6.43 & 6.24 \\
\hline & Medium & $82.16 \pm 0.0^{c}$ & $0.56 \pm 0.0^{\mathrm{a}}$ & $0.50 \pm 0.0^{\mathrm{a}}$ & $1.17 \pm 0.0^{\mathrm{a}}$ & 7.53 & 8.08 \\
\hline & Small & $85.18 \pm 0.0^{b}$ & $0.61 \pm 0.0^{\mathrm{a}}$ & $0.46 \pm 0.0^{\mathrm{a}}$ & $1.18 \pm 0.2^{\mathrm{a}}$ & 6.48 & 609 \\
\hline
\end{tabular}

${ }^{1}$ Average of the three repitition \pm standard deviation. ${ }^{2}$ Different lowercase letters in a column indicate statistic difference ( $\left.\mathrm{p} \leq 0,05\right)$ between the sizes (large, medium and small), for the same variety, for each item (water, ash, lipids, proteins, dietetic fiber and carbohidrate). ${ }^{3}$ Carbohydrates (HCO). 
Table 3. Soluble and insoluble dietary fiber ${ }^{1,2}$ in Citrus fruits without peel (g.100 g $\left.{ }^{-1}\right)$.

\begin{tabular}{|c|c|c|c|c|c|c|c|}
\hline \multicolumn{2}{|c|}{ Varieties } & \multirow{2}{*}{$\begin{array}{c}\text { Soluble Fiber } \\
2.21 \pm 0.2^{\mathrm{a}}\end{array}$} & \multirow{2}{*}{$\begin{array}{c}\text { Insoluble Fiber } \\
5.87 \pm 0.2^{\mathrm{b}}\end{array}$} & \multicolumn{2}{|c|}{ Varieties } & \multirow{2}{*}{$\begin{array}{c}\text { Soluble fiber } \\
0.75 \pm 0.1^{\mathrm{b}}\end{array}$} & \multirow{2}{*}{$\begin{array}{c}\text { Insoluble Fiber } \\
1.71 \pm 0.0^{\mathrm{b}}\end{array}$} \\
\hline Pêra & Large & & & Natal & Large & & \\
\hline & Medium & $2.42 \pm 0.3^{\mathrm{a}}$ & $5.91 \pm 0.5^{\mathrm{b}}$ & & Medium & $0.83 \pm 0.0^{\mathrm{ab}}$ & $1.68 \pm 0.0^{\mathrm{b}}$ \\
\hline & Small & $2.73 \pm 0.5^{\mathrm{a}}$ & $7.84 \pm 0.7^{\mathrm{a}}$ & & Small & $0.93 \pm 0.0^{\mathrm{a}}$ & $1.93 \pm 0.1^{\mathrm{a}}$ \\
\hline \multirow[t]{3}{*}{ Valência } & Large & $0.15 \pm 0.0^{\mathrm{b}}$ & $4.44 \pm 0.2^{\mathrm{a}}$ & Bahia & Large & $2.84 \pm 0.2^{\mathrm{b}}$ & $2.84 \pm 0.1^{\mathrm{b}}$ \\
\hline & Medium & $0.57 \pm 0.0^{\mathrm{a}}$ & $2.96 \pm 0.0^{\mathrm{b}}$ & & Medium & $3.29 \pm 0.0^{\mathrm{a}}$ & $2.87 \pm 0.0^{\mathrm{b}}$ \\
\hline & Small & $0.45 \pm 0.1^{\mathrm{a}}$ & $3.95 \pm 0.3^{\mathrm{a}}$ & & Small & $3.11 \pm 0.2^{\mathrm{a}}$ & $3.65 \pm 0.3^{\mathrm{a}}$ \\
\hline \multirow[t]{6}{*}{ Lima } & Large & $0.02 \pm 0.0^{\mathrm{b}}$ & $3.58 \pm 0.0^{\mathrm{b}}$ & Ponkan & Large & $2.23 \pm 0.2^{\mathrm{a}}$ & $2.81 \pm 0.0^{\mathrm{b}}$ \\
\hline & Medium & $0.88 \pm 0.7^{\mathrm{b}}$ & $2.66 \pm 0.0^{c}$ & & Medium & $0.07 \pm 0.0^{c}$ & $3.25 \pm 0.0^{\mathrm{a}}$ \\
\hline & Small & $3.06 \pm 0.2^{\mathrm{a}}$ & $6.88 \pm 0.2^{\mathrm{a}}$ & & Small & $0.83 \pm 0.0^{\mathrm{b}}$ & $2.82 \pm 0.0^{\mathrm{b}}$ \\
\hline & & & & Murcote & Large & $2.24 \pm 0.0^{c}$ & $4.19 \pm 0.1^{\mathrm{a}}$ \\
\hline & & & & & Medium & $2.95 \pm 0.1^{\mathrm{a}}$ & $4.58 \pm 1.1^{\mathrm{a}}$ \\
\hline & & & & & Small & $2.40 \pm 0.1^{\mathrm{b}}$ & $4.08 \pm 0.3^{\mathrm{a}}$ \\
\hline
\end{tabular}

${ }^{1}$ Average of the three repitition \pm standard deviation. ${ }^{2}$ Different lowercase letters in a column indicate statistic differences ( $\left.\mathrm{p} \leq 0,05\right)$ between the sizes (large, medium and small), for the same variety, for each item (insoluble and soluble fibers).

Souza et al. (2004). These variations are due to the climate and the maturation grade of the fruits.

'Pera', lime, 'Murcote' and 'Ponkan' fruits of small size presented the highest values of titratable acidity $(\mathrm{p} \leq 0.05)$. According to Villas Boas et al. (2002), the same occurred to the total solid soluble, as presented for 4 varieties of oranges. 'Natal' variety had the highest amount of total solid soluble for the large sized, but with no significant difference. That was observed in other components, too. For tangerines, the highest total soluble solid amount corresponded to the medium sized fruits. Titratable acidity and total solid soluble amounts presented the same averages as those presented by Sugai et al. (2002) and Iemma et al. (1999) for 'Pêra' orange and Villas Boas et al. (2002) and Raveh et al. (2009) for 'Valência' orange. Duenhas et al. (2002) and Cano, Medina and Bernajo (2008), who studied different citrus varieties, found higher averages for the same variety. Only 'Pera' orange presented a significant difference $(\mathrm{p} \leq 0.05)$ between sizes (Table 5), others presented a difference of one in relation to other two.

Ascorbic acid amount was higher than the average presented by USDA (UNITED..., 2009), Iemma et al. (1999) and TACO/UNICAMP (UNIVERSIDADE..., 2006), but tangerine values were lower than orange values, too, as shown in Table 6 .

Johnston and Hale (2005) found values for commercial orange juices at 1 day and 8 days of storage $\left(4^{\circ} \mathrm{C}\right), 29$ and $27 \mathrm{mg} .100 \mathrm{~mL}^{-1}$, respectively, and 38 and $49 \mathrm{mg} .100 \mathrm{~mL}^{-1}$ for frozen juice. The values are lower because the juices are reconstituted. Tiwari et al. (2009) concluded that different processes change the retention of ascorbic acid in orange juice during storage.

'Valencia' orange ascorbic acid amount was $40.64 \mathrm{mg} .100 \mathrm{~mL}^{-1}$ for fresh juice (SÂNCHEZ-MORENO et al., 2003), similar to the results of this research (Table 6). For 'Pera' variety, Souza et al. (2004) found values between 50 and $60 \mathrm{mg} \cdot \mathrm{mL}^{-1}$, from time zero until 72 hours of storage at $4{ }^{\circ} \mathrm{C}$.

Between varieties (Tabela 6), tangerines ('Murcote' and 'Ponkan') presented lower values immediately after extraction, similar to 'Valência' only. The same occurred after 24 hours at room temperature and at $4{ }^{\circ} \mathrm{C}$. The highest amount of ascorbic acid at all times was found for 'Bahia' orange, which differ from others ( $\mathrm{p} \leq 0.05)$ after 24 hours of storage, but at the moment of
Table 4. Total titratable acidity (TTA) $)^{1,2}$ and Total soluble solids (TSS) $)^{1,2}$ in citrus varieties.

\begin{tabular}{lcrc}
\hline Varieties & TTA $(\%)$ & TSS $(\%)$ & TSS/TTA \\
\hline Pêra & $1.8 \pm 0.1^{\mathrm{ab}}$ & $13.43 \pm 2.1^{\mathrm{a}}$ & 7.46 \\
Valência & $1.3 \pm 0.0^{\mathrm{ab}}$ & $9.37 \pm 0.8^{\mathrm{a}}$ & 7.21 \\
Lima & $0.3 \pm 0.0^{\mathrm{b}}$ & $10.47 \pm 4.0^{\mathrm{a}}$ & 34.90 \\
Natal & $1.6 \pm 0.0^{\mathrm{ab}}$ & $10.03 \pm 0.1^{\mathrm{a}}$ & 4.36 \\
Bahia & $2.3 \pm 0.0^{\mathrm{a}}$ & $9.13 \pm 2.3^{\mathrm{a}}$ & 3.97 \\
Ponkan & $1.6 \pm 0.1^{\mathrm{ab}}$ & $9.73 \pm 1.1^{\mathrm{a}}$ & 6.08 \\
Murcote & $1.2 \pm 0.0^{\mathrm{ab}}$ & $14.60 \pm 1.5^{\mathrm{a}}$ & 12.17 \\
\hline
\end{tabular}

${ }^{1}$ Average of the three sizes (small, medium and large) \pm standard deviation. ${ }^{2}$ Values within a column with different superscripts are significantly different at $\mathrm{p} \leq 0.05$ by tukey test.

Table 5. Total titratable acidity (TTA) $)^{1,2}$ and total soluble solids (TSS) ${ }^{1,2}$ in oranges and tangerines varieties by sizes.

\begin{tabular}{lcccc}
\hline & Varieties & TTA $(\%)$ & TSS (\%) & TSS/TTA \\
\hline \multirow{4}{*}{ Pêra } & Large & $1.8 \pm 0.0^{1 \mathrm{~b} 2}$ & $11.20 \pm 0.0^{\mathrm{c}}$ & 6.22 \\
& Medium & $0.5 \pm 0.0^{\mathrm{c}}$ & $13.80 \pm 0.0^{\mathrm{b}}$ & 27.6 \\
Valência & Small & $2.8 \pm 0.0^{\mathrm{a}}$ & $15.30 \pm 0.0^{\mathrm{a}}$ & 5.46 \\
& Large & $1.2 \pm 0.0^{\mathrm{b}}$ & $8.9 \pm 0.0^{\mathrm{b}}$ & 7.42 \\
& Medium & $1.4 \pm 0.0^{\mathrm{a}}$ & $8.9 \pm 0.0^{\mathrm{b}}$ & 6.36 \\
Lima & Small & $1.3 \pm 0.0^{\mathrm{ab}}$ & $10.3 \pm 0.0^{\mathrm{a}}$ & 7.92 \\
& Large & $0.2 \pm 0.0^{\mathrm{b}}$ & $8.00 \pm 0.0^{\mathrm{b}}$ & 40.00 \\
\multirow{4}{*}{ Natal } & Medium & $0.3 \pm 0.0^{\mathrm{b}}$ & $8.30 \pm 0.0^{\mathrm{c}}$ & 27.67 \\
& Small & $0.5 \pm 0.0^{\mathrm{a}}$ & $15.10 \pm 0.0^{\mathrm{a}}$ & 30.20 \\
& Large & $1.6 \pm 0.0^{\mathrm{a}}$ & $10.1 \pm 0.0^{\mathrm{a}}$ & 6.31 \\
Bahia & Medium & $1.4 \pm 0.0^{\mathrm{b}}$ & $10.0 \pm 0.0^{\mathrm{a}}$ & 7.14 \\
& Small & $1.7 \pm 0.0^{\mathrm{a}}$ & $10.0 \pm 0.0^{\mathrm{a}}$ & 5.88 \\
& Large & $2.4 \pm 0.0^{\mathrm{a}}$ & $7.00 \pm 0.0^{\mathrm{c}}$ & 2.92 \\
\multirow{4}{*}{ Ponkan } & Medium & $2.4 \pm 0.0^{\mathrm{a}}$ & $8.80 \pm 0.0^{\mathrm{b}}$ & 3.67 \\
& Small & $2.2 \pm 0.0^{\mathrm{b}}$ & $11.60 \pm 0.0^{\mathrm{a}}$ & 5.27 \\
& Large & $1.1 \pm 0.0^{\mathrm{b}}$ & $9.10 \pm 0.0^{\mathrm{b}}$ & 8.27 \\
& Medium & $1.1 \pm 0.0^{\mathrm{b}}$ & $11.00 \pm 0.0^{\mathrm{a}}$ & 10.0 \\
& Small & $2.5 \pm 0.0^{\mathrm{a}}$ & $9.10 \pm 0.0^{\mathrm{b}}$ & 3.64 \\
& Large & $1.0 \pm 0.0^{\mathrm{b}}$ & $13.40 \pm 0.0^{\mathrm{c}}$ & 13.40 \\
& Medium & $1.0 \pm 0.0^{\mathrm{b}}$ & $16.30 \pm 0.0^{\mathrm{a}}$ & 16.30 \\
& Small & $1.6 \pm 0.0^{\mathrm{a}}$ & $14.10 \pm 0.0^{\mathrm{b}}$ & 8.81 \\
\hline
\end{tabular}

${ }^{1}$ Means of three repetitions \pm standart deviation. ${ }^{2}$ Different letters in vertical indicam diferença estatística $(\mathrm{p} \leq 0,05)$ between sizes (large, medium and small) in the same variety. 
extraction, it was similar to 'Pêra' orange. The highest stability of ascorbic acid for 'Bahia' orange occurred because of the higher titratable acidity (Table 4), which preserved the ascorbic acid oxidation (BURDURLU; KOCA; KARADENIZ, 2006). All samples showed a decrease in the ascorbic acid amount $(\mathrm{p} \leq 0.05)$ after storage at room temperature and at $4{ }^{\circ} \mathrm{C}$, but only 'Ponkan' tangerine presented a significant difference $(\mathrm{p} \leq 0.05)$ between the two storage temperatures.

'Bahia' orange presented higher ascorbic acid amount, with an average of $70.10 \mathrm{mg} .100 \mathrm{~g}^{-1}$, while tangerines presented lower amounts: $37.26 \mathrm{mg} .100 \mathrm{~g}^{-1}$ for 'Murcote' and $38.99 \mathrm{mg} .100 \mathrm{~g}^{-1}$ for 'Ponkan'. Tangerines presented lower losses during storage, too.

Ascorbic acid degradation in packaged fruit juices depends mainly on the following: storage temperature, dissolved oxygen level, residual $\mathrm{H}_{2} \mathrm{O}_{2}$ remnant after packaging material sterilization, and metal ions traces (ÖZKAN; KIRCA; CEMEROGLU, 2004).
Ascorbic acid is one of the substances that contribute to the antioxidant capacity in juices. It contributes to 56 to $77 \%$ of the antioxidant capacity of orange juice, $46 \%$ of the tangerine juice and 66 to $77 \%$ of grapefruit juice (VINSON et al., 2002).

Oranges have antioxidants (RAPISARDA et al., 1999) in greater quantities for protection against ascorbic acid oxidation. One of them is the flavonoids group, as presented by Miller and Rice Evans (1997), who studied the effect of polyphenols in the protection of vitamin $\mathrm{C}$ in juices. They protect the ascorbic acid against oxidation (DAUCHET et al., 2008; GHASEMI; GHASEMI, EBRAHINZADEH, 2009; XU et al., 2008)

Other important factor in the ascorbic acid stabilization in solution is the quantity of oxygen dissolved (KISHIDA et al., 2004), but this factor was constant for the analyzed juice.

Observing Table 7 , small tangerines in storage at $4{ }^{\circ} \mathrm{C}$ presented good conservation of ascorbic acid, and did not differ

Table 6. Ascorbic acid (mg.100 $\left.\mathrm{g}^{-1}\right)^{1,2,3}$ and porcetage of lost ${ }^{1,2,3}$ after storage at room temperature and $4^{\circ} \mathrm{C}$ in juices by variety.

\begin{tabular}{|c|c|c|c|c|c|}
\hline Varieties & $\begin{array}{c}\text { Ascorbic acid immediatily } \\
\text { after extraction }\end{array}$ & $\begin{array}{c}\text { Ascorbic acid after } \\
24 \text { hours at room temperature }\end{array}$ & $\%$ lost & $\begin{array}{l}\text { Ascorbic acid after } \\
24 \text { hours at } 4{ }^{\circ} \mathrm{C}\end{array}$ & $\%$ lost \\
\hline Valência & $42.35 \pm 1.8^{\mathrm{cA}}$ & $36.76 \pm 2.8^{\mathrm{cB}}$ & 13.20 & $37.65 \pm 2.2^{\mathrm{cB}}$ & 11.11 \\
\hline Natal & $55.40 \pm 3.4^{\mathrm{bA}}$ & $48.66 \pm 3.8^{\mathrm{bB}}$ & 12.18 & $51.47 \pm 3.0^{\mathrm{bB}}$ & 7.11 \\
\hline Bahia & $70.10 \pm 1.6^{\mathrm{aA}}$ & $62.53 \pm 2.8^{\mathrm{aB}}$ & 10.81 & $63.79 \pm 1.4^{\mathrm{a} B}$ & 9.01 \\
\hline
\end{tabular}

${ }^{1}$ Average of the three sizes (small, medium and large) \pm standard deviation. ${ }^{2}$ Values within a column with different lowercase superscripts are significantly different at $\mathrm{p} \leq 0.05$ by tukey test for varieties, in each item. ${ }^{3}$ Values within a line with different uppercase superscripts are significantly different at $\mathrm{p} \leq 0.05$ by tukey test for storage temperatures.

Table 7. Ascorbic acid (mg. $\left.100 \mathrm{~g}^{-1}\right)^{1,2,3}$ and percentage of lost ${ }^{1,2,3}$ after storage at room temperature and $4{ }^{\circ} \mathrm{C}$ in juices by sizes.

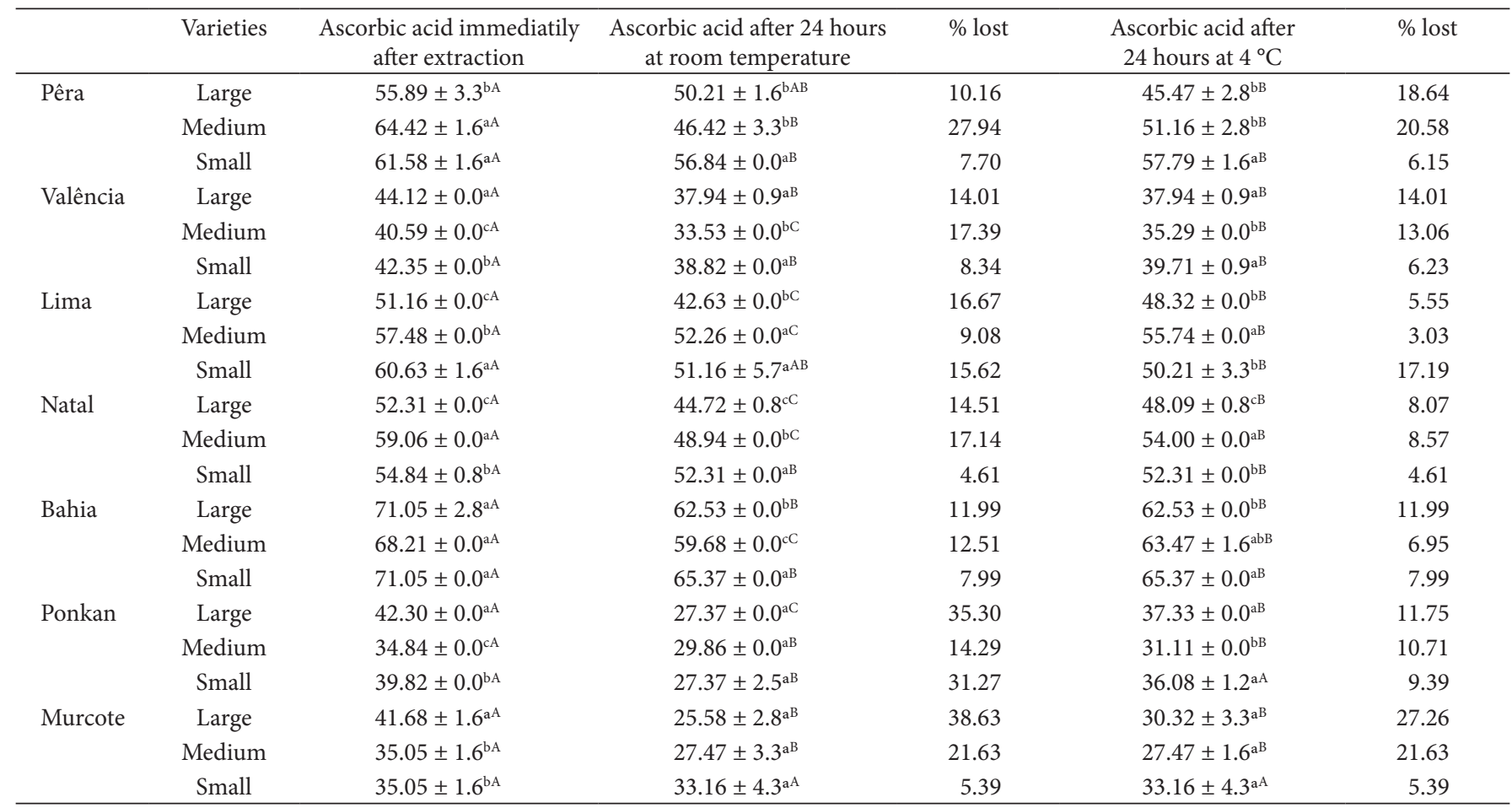

${ }^{1}$ Average of the three repitition \pm standard deviation. ${ }^{2}$ Values within a column with different lowercase superscripts are significantly different at $\mathrm{p} \leq 0.05$ by tukey test for sizes, in each variety. ${ }^{3}$ Values within a line with different uppercase superscripts are significantly different at $\mathrm{p} \leq 0.05$ by tukey test for storage temperatures. 
significantly from control ( $p \leq 0.05)$. For 'Murcote' tangerine, small sized fruits did not present significant difference after 24 hours. Considering percentage loss, in general, small fruits lost less, except 'Lima' and 'Bahia' at $4{ }^{\circ} \mathrm{C}$ storage, and 'Lima' and 'Ponkan' at room temperature storage. Storage, at room temperature or at $4{ }^{\circ} \mathrm{C}$, interferes in the loss of ascorbic acid, all varieties and sizes had some loss. All varieties and sizes showed a decrease in the amount of ascorbic acid, regardless the size, only 'Murcote' tangor did not present differences between sizes $(\mathrm{p} \leq 0.05)$. The highest loss percentage was observed in large sized 'Murcote' tangor at room temperature.

Table 8 shows the albedo as the highest pectin level part. The second highest value was found in the peel of the oranges, and in the pulp of the tangerines. The 'Natal' and 'Valência' oranges presented the lowest values of total pectin in juice. 'Murcote' tangor pectin contents stood out both in solid parts as in juice.
The values showed in Table 8 are very close to those related by Mendez et al. (2001), but they are higher in 'Murcote' tangerine and lower in 'Lima' orange, maybe because they were cultured in different weather conditions in the second case. Mendez et al. (2001) did not analyze the fruits in parts or sizes, but the whole fruits.

Considering all the solid parts of the fruit (Table 9), the highest values for pectin were found in the small sized 'Pêra' and 'Lima' oranges and in the medium sized 'Ponkan' tangerine and 'Bahia' and 'Valência' oranges. In 'Natal' orange, the highest pectin content in albedo was found in the large sized oranges and in the small sized orange peel and pulp. In 'Murcote' tangor, the highest content was found in the large sized tangerine albedo and pulp and in the medium and small sized tangerine peel.

Table 10 shows pectin values (total and soluble) in juice. They do not have any relation to the fruits sizes. However, in

Table 8. Total and soluble pectin ${ }^{1,2}$ amount in Citrus fruits (solids part g. $100 \mathrm{~g}^{-1}$ and juice $\mathrm{mg} 100 \mathrm{~g}^{-1}$ ).

\begin{tabular}{lccccc}
\hline \multicolumn{1}{c}{ Varieties } & Peel - total pectin & Albedo - total pectin & Pulp - total pectin & Juice - total pectin & Juice - soluble pectin \\
\hline Pêra & $0.38 \pm 0.1^{\mathrm{ab}}$ & $0.55 \pm 0.2^{\mathrm{ab}}$ & $0.29 \pm 0.1^{\mathrm{ab}}$ & $10.76 \pm 1.4^{\mathrm{ab}}$ & $7.89 \pm 1.6^{\mathrm{ab}}$ \\
Valência & $0.23 \pm 0.1^{\mathrm{bc}}$ & $0.60 \pm 0.2^{\mathrm{ab}}$ & $0.10 \pm 0.0^{\mathrm{bc}}$ & $7.69 \pm 1.0^{\mathrm{b}}$ & $3.46 \pm 0.8^{\mathrm{b}}$ \\
Lima & $0.28 \pm 0.1^{\mathrm{abc}}$ & $0.37 \pm 0.1^{\mathrm{b}}$ & $0.21 \pm 0.1^{\mathrm{bc}}$ & $8.61 \pm 1.0^{\mathrm{ab}}$ & $8.21 \pm 0.7^{\mathrm{ab}}$ \\
Natal & $0.13 \pm 0.1^{\mathrm{c}}$ & $0.43 \pm 0.0^{\mathrm{b}}$ & $0.07 \pm 0.0^{\mathrm{c}}$ & $7.46 \pm 2.3^{\mathrm{b}}$ & $4.58 \pm 1.1^{\mathrm{ab}}$ \\
Bahia & $0.34 \pm 0.1^{\mathrm{ab}}$ & $0.45 \pm 0.1^{\mathrm{b}}$ & $0.29 \pm 0.1^{\mathrm{ab}}$ & $10.23 \pm 1.9^{\mathrm{ab}}$ & $7.80 \pm 5.0^{\mathrm{ab}}$ \\
Ponkan & $0.23 \pm 0.0^{\mathrm{bc}}$ & $0.37 \pm 0.0^{\mathrm{b}}$ & $0.25 \pm 0.0^{\mathrm{bc}}$ & $11.47 \pm 1.3^{\mathrm{ab}}$ & $10.54 \pm 2.4^{\mathrm{a}}$ \\
Murcote & $0.43 \pm 0.0^{\mathrm{a}}$ & $0.76 \pm 0.1^{\mathrm{a}}$ & $0.48 \pm 0.3^{\mathrm{a}}$ & $12.26 \pm 1.7^{\mathrm{a}}$ & $11.07 \pm 2.2^{\mathrm{a}}$ \\
\hline
\end{tabular}

${ }^{1}$ Average of the three sizes (small, medium and large) \pm standard deviation. ${ }^{2}$ Different lowercase letters in a column indicate statistic differences $(\mathrm{p} \leq 0.05)$ between the varieties, for each item (peel, albedo, pulp, total pectin in juice and soluble pectin in juice).

Table 9. Total pectin ${ }^{1,2}$ amount in solids part of fresh Citrus fruits (g.100 $\mathrm{g}^{-1}$ ) by sizes.

\begin{tabular}{|c|c|c|c|c|}
\hline \multirow[t]{2}{*}{ Varieties } & \multirow[t]{2}{*}{ Part } & \multicolumn{3}{|c|}{ Sizes } \\
\hline & & Large & Medium & Small \\
\hline \multirow[t]{3}{*}{ Pêra } & Peel & $0.34 \pm 0.0^{\mathrm{b}}$ & $0.35 \pm 0.0^{\mathrm{b}}$ & $0.45 \pm 0.0^{\mathrm{a}}$ \\
\hline & Albedo & $0.40 \pm 0.0^{c}$ & $0.48 \pm 00^{\mathrm{b}}$ & $0.77 \pm 0.0^{\mathrm{a}}$ \\
\hline & Pulp & $0.22 \pm 0.0^{c}$ & $0.26 \pm 0.0^{\mathrm{b}}$ & $0.38 \pm 0.0^{\mathrm{a}}$ \\
\hline \multirow[t]{3}{*}{ Valência } & Peel & $0.14 \pm 0.0^{c}$ & $0.28 \pm 0.0^{\mathrm{a}}$ & $0.26 \pm 0.0^{\mathrm{b}}$ \\
\hline & Albedo & $0.42 \pm 0.0^{\mathrm{b}}$ & $0.68 \pm 0.0^{\mathrm{a}}$ & $0.71 \pm 0.0^{\mathrm{a}}$ \\
\hline & Pulp & $0.08 \pm 0.0^{\mathrm{b}}$ & $0.10 \pm 0.0^{\mathrm{a}}$ & $0.11 \pm 0.0^{\mathrm{a}}$ \\
\hline \multirow[t]{3}{*}{ Lima } & Peel & $0.21 \pm 0.0^{c}$ & $0.27 \pm 0.0^{\mathrm{b}}$ & $0.35 \pm 0.0^{\mathrm{a}}$ \\
\hline & Albedo & $0.28 \pm 0.0^{\mathrm{b}}$ & $0.42 \pm 0.0^{\mathrm{a}}$ & $0.41 \pm 0.0^{\mathrm{a}}$ \\
\hline & Pulp & $0.17 \pm 0.0^{\mathrm{b}}$ & $0.13 \pm 0.0^{c}$ & $0.32 \pm 0.0^{\mathrm{a}}$ \\
\hline \multirow[t]{3}{*}{ Natal } & Peel & $0.10 \pm 0.0^{\mathrm{b}}$ & $0.06 \pm 0.0^{\mathrm{b}}$ & $0.23 \pm 0.0^{\mathrm{a}}$ \\
\hline & Albedo & $0.47 \pm 0.0^{\mathrm{a}}$ & $0.42 \pm 0.0^{\mathrm{b}}$ & $0.39 \pm 0.0^{c}$ \\
\hline & Pulp & $0.03 \pm 0.0^{c}$ & $0.07 \pm 0.0^{\mathrm{b}}$ & $0.09 \pm 0.0^{\mathrm{a}}$ \\
\hline \multirow[t]{3}{*}{ Bahia } & Peel & $0.28 \pm 0.0^{\mathrm{b}}$ & $0.39 \pm 0.0^{\mathrm{a}}$ & $0.36 \pm 0.0^{\mathrm{a}}$ \\
\hline & Albedo & $0.41 \pm 0.0^{\mathrm{b}}$ & $0.52 \pm 0.0^{\mathrm{a}}$ & $0.41 \pm 0.0^{\mathrm{b}}$ \\
\hline & Pulp & $0.25 \pm 0.0^{c}$ & $0.36 \pm 0.0^{\mathrm{a}}$ & $0.26 \pm 0.0^{\mathrm{b}}$ \\
\hline \multirow[t]{3}{*}{ Ponkan } & Peel & $0.22 \pm 0.0^{c}$ & $0.24 \pm 0.0^{\mathrm{a}}$ & $0.23 \pm 0.0^{\mathrm{b}}$ \\
\hline & Albedo & $0.34 \pm 0.0^{c}$ & $0.39 \pm 0.0^{\mathrm{a}}$ & $0.37 \pm 0.0^{\mathrm{b}}$ \\
\hline & Pulp & $0.21 \pm 0.0^{c}$ & $0.29 \pm 0.0^{\mathrm{a}}$ & $0.25 \pm 0.0^{\mathrm{b}}$ \\
\hline \multirow[t]{3}{*}{ Murcote } & Peel & $0.38 \pm 0.0^{\mathrm{b}}$ & $0.46 \pm 0.0^{\mathrm{a}}$ & $0.46 \pm 0.0^{\mathrm{a}}$ \\
\hline & Albedo & $0.87 \pm 0.0^{\mathrm{a}}$ & $0.72 \pm 0.0^{\mathrm{b}}$ & $0.69 \pm 0.0^{c}$ \\
\hline & Pulp & $0.61 \pm 0.0^{\mathrm{a}}$ & $0.34 \pm 0.0^{c}$ & $0.50 \pm 0.0^{\mathrm{b}}$ \\
\hline
\end{tabular}

${ }^{1}$ Average of the three repitition \pm standard deviation. ${ }^{2}$ Different lowercase letters in a horizontal line indicate statistic differences $(\mathrm{p} \leq 0,05)$ between the sizes (large, medium and small), for the same variety, for each item (peel, albedo and pulp).
Table 10. Total and soluble pectin amount (mg.100 $\left.\mathrm{g}^{-1}\right)$ in juice by different sizes.

\begin{tabular}{|c|c|c|c|}
\hline \multirow[t]{2}{*}{ Varieties } & \multirow[t]{2}{*}{ Size } & \multicolumn{2}{|c|}{ Pectin } \\
\hline & & Soluble & Total \\
\hline \multirow[t]{3}{*}{ Pêra } & Large & $6.33 \pm 0.2^{1 \mathrm{c} 2}$ & $9.47 \pm 0.1^{c}$ \\
\hline & Medium & $7.79 \pm 0.1^{\mathrm{b}}$ & $10.60 \pm 0.1^{\mathrm{b}}$ \\
\hline & Small & $9.56 \pm 0.1^{\mathrm{a}}$ & $12.22 \pm 0.1^{\mathrm{a}}$ \\
\hline \multirow[t]{3}{*}{ Valência } & Large & $4.37 \pm 0.1^{\mathrm{a}}$ & $8.71 \pm 0.1^{\mathrm{a}}$ \\
\hline & Medium & $2.91 \pm 0.0^{c}$ & $7.59 \pm 0.0^{b}$ \\
\hline & Small & $3.10 \pm 0.1^{\mathrm{b}}$ & $6.78 \pm 0.1^{\mathrm{c}}$ \\
\hline \multirow[t]{3}{*}{ Lima } & Large & $7.40 \pm 0.3^{b}$ & $7.43 \pm 0.2^{\mathrm{b}}$ \\
\hline & Medium & $8.50 \pm 0.0^{\mathrm{a}}$ & $9.11 \pm 0.0^{\mathrm{a}}$ \\
\hline & Small & $8.73 \pm 0.0^{\mathrm{a}}$ & $9.28 \pm 0.0^{\mathrm{a}}$ \\
\hline \multirow[t]{3}{*}{ Natal } & Large & $4.04 \pm 0.0^{\mathrm{b}}$ & $8.82 \pm 0.1^{\mathrm{a}}$ \\
\hline & Medium & $5.87 \pm 0.1^{\mathrm{a}}$ & $8.73 \pm 0.4^{\mathrm{a}}$ \\
\hline & Small & $3.84 \pm 0.1^{c}$ & $4.82 \pm 0.2^{\mathrm{b}}$ \\
\hline \multirow[t]{3}{*}{ Bahia } & Large & $2.06 \pm 0.0^{c}$ & $8.17 \pm 0.0^{c}$ \\
\hline & Medium & $11.38 \pm 0.1^{\mathrm{a}}$ & $11.76 \pm 0.1^{\mathrm{a}}$ \\
\hline & Small & $9.95 \pm 0.0^{\mathrm{b}}$ & $10.76 \pm 0.0^{\mathrm{b}}$ \\
\hline \multirow[t]{3}{*}{ Ponkan } & Large & $7.82 \pm 0.1^{\mathrm{c}}$ & $10.19 \pm 0.2^{c}$ \\
\hline & Medium & $11.40 \pm 0.2^{\mathrm{b}}$ & $11.53 \pm 0.1^{\mathrm{b}}$ \\
\hline & Small & $12.41 \pm 0.1^{\mathrm{a}}$ & $12.70 \pm 0.2^{\mathrm{a}}$ \\
\hline \multirow[t]{3}{*}{ Murcote } & Large & $8.60 \pm 0.4^{c}$ & $10.61 \pm 0.1^{\mathrm{c}}$ \\
\hline & Medium & $11.94 \pm 0.1^{\mathrm{b}}$ & $12.27 \pm 0.0^{\mathrm{b}}$ \\
\hline & Small & $12.68 \pm 0.1^{\mathrm{a}}$ & $13.91 \pm 0.2^{\mathrm{a}}$ \\
\hline
\end{tabular}

${ }^{1}$ Average of the three repetition \pm standard deviation. ${ }^{2}$ different lowercase letters in a column indicate statistic differences $(\mathrm{p} \leq 0.05)$ between the sizes (large, medium and small), for the same variety, for each item (total and soluble pectin). 
most samples, the highest pectin contents were observed in small sized fruits.

\section{Conclusions}

Although differences have been found between sizes, they were not uniform, in small amount or even inexistent.

The total soluble solids are higher in medium sized tangerine and smaller oranges.

Tangerines present lower quantity of ascorbic acid than oranges, except for the 'Valencia' variety.

Percentage of vitamin $\mathrm{C}$ loss in different varieties was independent of storage temperature, except for 'Ponkan' tangerine. fruits.

Albedo presented the highest content of pectin of all studied

In juice, the total and soluble pectin contents increased as fruits size decreased.

Different oranges and tangerines differ in the amount of pectin.

\section{Acknowledgements}

I wish to express my gratitude to Raphael Juliano and Adriano, who kindly provided the fruits for this project; and especially to FAPESP, for the scientific and financial supports.

\section{References}

ASP, N. G. et al. Rapid enzimatic assay of insoluble and soluble dietary fiber. Journal of Agricultural and Food Chemistry, v. 31, n. 3, p. 476-482, 1983. PMid:6309935. http://dx.doi.org/10.1021/ jf00117a003

ASSOCIAÇÃO BRASILEIRA EXPORTADORES DE CÍTRICOS ABECITRUS. The Brazilian Association for Citrus Exporters. 2005. Disponível em: $<$ www.abecitrus.com.br/indus.html $>$. Acesso em: maio 2005.

ASSOCIATION OF OFFICIAL ANALYTICAL CHEMISTS - AOAC. Official methods of analysis of the Association of Official Analytical Chemists. 16th. ed. Washington: AOAC, 1995. v. 2.

BECERRA-RODRIGUEZ, S. et al. Performance of various grapefruit (Citrus paradini Macf.) and pummelo (C. maxima Merr.) cultivars under the dry tropic conditions of Mexico. Euphytica, v. 164, n. 1, p. 27-36, 2008. http://dx.doi.org/10.1007/s10681-007-9627-8

BITTER, V;; MUIR, H. M. A modified uronic acid carbazole reaction. Analytical Biochemistry, v. 4, n. 4, p. 330-334, 1962. http://dx.doi. org/10.1016/0003-2697(62)90095-7

BRUMMELL, D. A. Cell Wall disassembly in ripening fruit. Functional Plant Biology, v. 33, n. 2, p. 103-119, 2006. http://dx.doi. org/10.1071/FP05234

BURDURLU, H. S.; KOCA, N.; KARADENIZ, F. Degradation of vitamin $C$ in citrus juice concentrates during storage. Journal of Food Engineering, v. 74, n. 2, p. 211-216, 2006. http://dx.doi. org/10.1016/j.jfoodeng.2005.03.026

CANO, A.; MEDINA, A.; BERMEJO, A. Bioactive compounds in different citrus varieties. Discrimination among cultivars. Journal of Food Composition and Analysis, v. 21, n. 5, p. 377-381, 2008. http://dx.doi.org/10.1016/j.jfca.2008.03.005

CIPRIANI, T. R. et al. Influence of molecular weight of chemically sulfated citrus pectin fractions or their antithrombotic and bleeding effect. Thrombosis and Haemostasis, v. 101, n. 5, p. 860-866, 2009. PMid:19404539.

DAUCHET, L. et al. Relationships between different types of fruit and vegetable consumption and serum concentrations of antioxidant vitamins. British Journal of Nutrition, v. 100, n. 3, p. 633-641, 2008. PMid:18279554.

DUENHAS, L. H. et al. Fertigation with different doses of NPK and its effects on fruit yield and quality of Valencia orange (Citrus Sinensis Osbeck). Revista Brasileira de Fruticultura, v. 24, n. 1, p. 214-218, 2002. http://dx.doi.org/10.1590/S0100-29452002000100046

FIETZ, V. R.; SALGADO, J. M. Efeito da pectina e celulose os níveis séricos de colesterol e triglicerídeos em ratos hiperlipidêmicos. Ciência e Tecnologia de Alimentos, v. 19, n. 3, p. 318-321, 1999.

FRANCO, G. (Ed.). Tabela de composição química dos alimentos. 9. ed. Rio de Janeiro: Livraria Atheneu Editora, 2001.

GHASEMI, K.; GASEMI, Y.; EBRAHINZADEH, M. A. Antioxidant activity, phenol and flavanoid contents of 13 citrus species peels and tissues. Pakistan Journal of Pharmaceutical Sciences, v. 22, n. 3, p. 277-281, 2009.

GRUPO COLT. 2003. Disponível em: <www.grupocolt.com.br/ laranja2.html >. Acesso em: jun. 2003.

HASSE, G. (Ed.). A Laranja no Brasil. São Paulo: Duprat e Iobe Propaganda, 1987.

IEMMA, J. et al. Gamma radiation and the conservation of natural orange juice. Scientia Agricola, v. 56, n. 4, p. 1193-1198, 1999. Suplemento.

JACOBS, M. B. (Ed.). The chemical analysis of foods and food products. New York: Van Nostrand, 1958.

JOHNSTON, C. S.; HALE, J. C. Oxidation of ascorbic in stored orange juice is associated with reduced plasma vitamin $\mathrm{C}$ concentrations and elevated lipid peroxides. Journal of the American Dietetic Association, v. 105, n. 2, p. 106-109, 2005. PMid:15635354. http:// dx.doi.org/10.1016/j.jada.2004.10.026

KANG, H. J. et al. Effect of citrus pectin oligosaccharide prepared by irradiation high cholesterol diet B6KOR-CpoE Mice. Food Science and Biotechnology, v. 18, n. 4, p. 884-888, 2009.

KISHIDA, E. et al. Effects of seasonings on the stability of ascorbic acid in a cooking model system. Journal of Nutritional Science and Vitaminology, v. 50, n. 6, p. 431-437, 2004.

LEME JUNIOR, J.; MALAVOLTA, E. Determinação fotométrica de ácido ascórbico. Anais da Escola Superior de Agricultura Luiz de Queiroz, v. 7, p. 115-129, 1950.

LESTER, G. E.; JIFON, J. L.; ROGER, G. Supplemental foliar potassium application during muskmelon fruit development can improve fruit quality, ascorbic acid, and beta-carotene contents. Journal of the American Society for Horticultural Science, v. 130, n. 4, p. 649-653, 2005.

MAFRA, I. et al. Ripening-related changes in the cell walls of olive (Olea europaea L.) pulp of two consecutive harvests. Journal of the Science of Food and Agriculture, v. 86, n. 6, p. 988-998, 2006. http://dx.doi.org/10.1002/jsfa.2447

McCREAD, P. M.; McCOMB, E. A. Extraction and determination of total pectin materials. Analytical Chemistry, v. 24, n. 12, p. 19861988, 1952. http://dx.doi.org/10.1021/ac60072a033 
MENDEZ, M. H. M. et al. Tabela de Composição de Alimentos. Rio de Janeiro: Universidade Federal Fluminense, 2001.

METZGER, B. T.; BARNES, D. M.; REED, J. D. A comparison of pectin, polyphenols, and phytosterols, alone or in combination, to Lovastatin for reduction of serum lipids in familial hypercholesterolemic swine. Journal of Medicinal Food, v. 12, n. 4, p. 854-860, 2009. PMid:19735187. http://dx.doi.org/10.1089/jmf.2008.0140

MILLER, N. J.; RICE-EVANS, C. A. The relative contributions of ascorbic acid and phenolic antioxidnats to the total antioxidant activity of orange and apple fruit juices and blackcurrant drink. Food Chemistry, v. 60, n. 3, p. 331-337, 1997. http://dx.doi. org/10.1016/S0308-8146(96)00339-1

OFICINA REGIONAL PARA AMÉRICA LATINA Y EL CARIBE RLC; FOOD AND AGRICULTURE ORGANIZATION - FAO. Oficina Regional de la FAO para America Latina y el Caribe. 2004. Disponível em: <www.rlc.fao.org>. Acesso em: out. 2004.

OVODOV, Y. S. Current views on pectin substances. Russian Journal of Bioorganic Chemistry, v. 35, n. 3, p. 269-284, 2009. http://dx.doi. org/10.1134/S1068162009030017

ÖZKAN, M.; KIRCA, A.; CEMEROGLU, B. Effects of hydrogen peroxide on the stability of acorbic acid during storage in various fruit juices. Food Chemistry, v. 88, n. 4, p. 591-597, 2004.

PESTANA, M. et al. Relationships between nutrient composition of flowers and fruit quality in orange trees grown in calcareous soil. Tree Physiology, v. 25, n. 6, p. 761-767, 2005. PMid:15805096

PIEDADE, J.; CANNIATTI-BRAZACA, S. G. Comparação entre o efeito do resíduo do abacaxizeiro (caules e folhas) e de pectina cítrica de alta metoxilação no nível de colesterol sanguíneo em ratos. Ciência e Tecnologia de Alimentos, v. 23, n. 2, p. 149-156, 2003. http://dx.doi.org/10.1590/S0101-20612003000200008

PREGNOLATTO, W. (Ed.). Normas analíticas do Instituto Adolfo Lutz. Métodos químico-físicos para análise de alimentos. 3. ed. São Paulo: Instituto Adolfo Lutz, 1985.

RAI, P. et al. Modeling of sucrose permeation through a pectin gel during ultrafiltration of depectinized mosambi (Citrus sinensis (L.) Osbeck) juice. Journal of Food Science, v. 71, n. 2, p. E87-E94, 2006. http://dx.doi.org/10.1111/j.1365-2621.2006.tb08901.x

RAPISARDA, P. et al. Antioxidant effectiveness as influenced by phenolic content of fresh orange juices. Journal of Agricultural and Food Chemistry, v. 47, n. 11, p. 4718-4723, 1999. PMid:10552879. http://dx.doi.org/10.1021/jf9901111

RAPISARDA, P. et al. Juice of new citrus hybrids (Citrus clementina Hort. Ex $\tan x$ C. sinensis L. Osbeck) as a source of natural antioxidants. Food Chemistry, v. 117, n. 2, p. 212-218, 2009. http:// dx.doi.org/10.1016/j.foodchem.2009.03.101
RAVEH, E. et al. Influence of rootstock and scion on antioxidant capacity of juice from new pomelo and mandarin varieties. Journal of Science of Food Agriculture, v. 89, n. 11, p. 1825-1830, 2009. http://dx.doi.org/10.1002/jsfa.3639

SANCHEZ-MORENO, C. et al. Vitamin C, provitamin A Carotenoids, and other carotenoids in high-ressurized orange juice during refrigerated storage. Journal of Agricultural and Food Chemistry, v. 51, n. 3, p. 647-653, 2003. PMid:12537436. http://dx.doi. org/10.1021/jf020795o

SOUZA, M. C. C. et al. Stability of unpasteurized and refrigerated orange juice. Brazilian Archives of Biology and Technology, v. 47 , n. 3, p. 391-397, 2004. http://dx.doi.org/10.1590/S151689132004000300009

STATISTICAL ANALYSIS SYSTEM INSTITUTE - SAS. Sas/Qc software: usage and reference. 2th ed. Cary: SAS, 1996. v. 2.

SUGAI, A. Y. et al. Physico-chemical and microbiological analyses of minimally processed orange juice stored in aluminium cans. Ciência e Tecnologia de Alimentos, v. 22, n. 3, p. 233-238, 2002.

TIWARI, B. K. et al. Ascorbic acid degradation kinetics of sonicated orange juice during storage and comparison with thermally pasteurized juice. LWT Food Science and Technology, v. 42, n. 3, p. 700-704, 2009. http://dx.doi.org/10.1016/j.lwt.2008.10.009

UNITED STATES DEPARTMENT OF AGRICULTURE - USDA. Food composition databasis. 2009. Disponível em: <www.nal.usda.gov/ fnic/foodcomp/searchRelease22>. Acesso em: nov. 2009.

UNIVERSIDADE DE SÃO PAULO. Faculdade de Ciências Farmacêuticas. Tabela de Composição de Alimentos. 2008. Disponível em: <www.fcf.usp.br>. Acesso em: nov. 2009.

UNIVERSIDADE ESTADUAL DE CAMPINAS - UNICAMP. Tabela de Composição de Alimentos - TACO. 2006. versão 2. 2. ed. Disponível em: <www.unicamp.br/nepa/taco/contar/taco_versao2. phf $>$. Acesso em: nov. 2009.

VILLAS BOAS, R. L. et al. Nutrients levels of leaf, juice quality and roots fresh weight of orange due irrigation and fertigation. Revista Brasileira de Fruticultura, v. 24, n. 1, p. 231-235, 2002.

VINSON, J. A. et al. Polyphenol antioxidants in citrus juices: in vitro and in vivo studies relevant to heart disease. Advances in Experimental Medicine and Biology, v. 505, p. 113-122, 2002. PMid:12083455

$\mathrm{XU}, \mathrm{G}$. H. et al. Juice components and antioxidant capacity of citrus varieties cultivated in China. Food Chemistry, v. 106, n. 2, p. 545-551, 2008. http://dx.doi.org/10.1016/j.foodchem.2007.06.046

ZYKWINSKA, A. et al. "Green labelled" pectins with gelling and emulsifying properties can be extracted by enzymatic way from unexploited sources. Food hydrocolloids, v. 23, n. 8, p. 2468-2477, 2009. http://dx.doi.org/10.1016/j.foodhyd.2009.07.010 